\title{
Diversification of Eupolypods in Mid-Cretaceous-Evidenced by Myanmar Amber Forest
}

\author{
Cunxiang Li ${ }^{*}$, Libing Zhang',3 \\ ${ }^{1}$ State Key Laboratory of Palaeobiology and Stratigraphy, Center for Excellence in Life and Palaeoenvironment, Nanjing Institute \\ of Geology and Palaeontology, Nanjing, China \\ ${ }^{2}$ Missouri Botanical Garden, St. Louis, Missouri, USA \\ ${ }^{3}$ Chengdu Institute of Biology, Chinese Academy of Sciences, Chengdu, China \\ Email: *cxli@nigpas.ac.cn
}

How to cite this paper: Li, C.X. and Zhang, L.B. (2019) Diversification of Eupolypods in Mid-Cretaceous-Evidenced by Myanmar Amber Forest. Open Journal of Geology, 9, 726-730. https://doi.org/10.4236/ojg.2019.910086

Received: August 30, 2019

Accepted: September 24, 2019

Published: September 27, 2019

Copyright $\odot 2019$ by author(s) and Scientific Research Publishing Inc. This work is licensed under the Creative Commons Attribution International License (CC BY 4.0).

http://creativecommons.org/licenses/by/4.0/ (c) (i) Open Access

\begin{abstract}
The evolutionary history of Eupolypods still remains unclear, especially on its diversification scenarios. In recent years, it has been found that approximately 100 million-year-old Myanmar amber provides a unique source of polypod fossils. Different families and numerous sporangia, spores, and scales have been found in Myanmar amber. These discoveries are nevertheless important because they provided the first unequivocal fossil evidence that the diversity of eupolypod ferns was present already in the mid-Cretaceous Myanmar amber forest. This clearly shows that Eupolypods originated before mid-Cretaceous, probably as early as the Early Jurassic, which is consistent with the recent divergence time estimate based on molecular dating.
\end{abstract}

\section{Keywords}

Mid-Cretaceous, Myanmar Amber, Eupolypods, Divergence Time

In the last two decades, unprecedented progress has been made by employing DNA sequence data and phylogenetic approaches toward a full understanding of the relationships that shape the major branches of the fern tree of life. In 2006, these phylogenetic hypotheses were consolidated and presented in a revised classification for ferns [1]. Smith et al. [1] recognized a monophyletic order Polypodiales ("Polypods", Figure 1), and most species within the order belong to the Eupolypods, composed of two clades: Eupolypods I and Eupolypods II [2] [3]. Together, the eupolypod lineages include nearly 6000 species-more than half of extant fern diversity. 


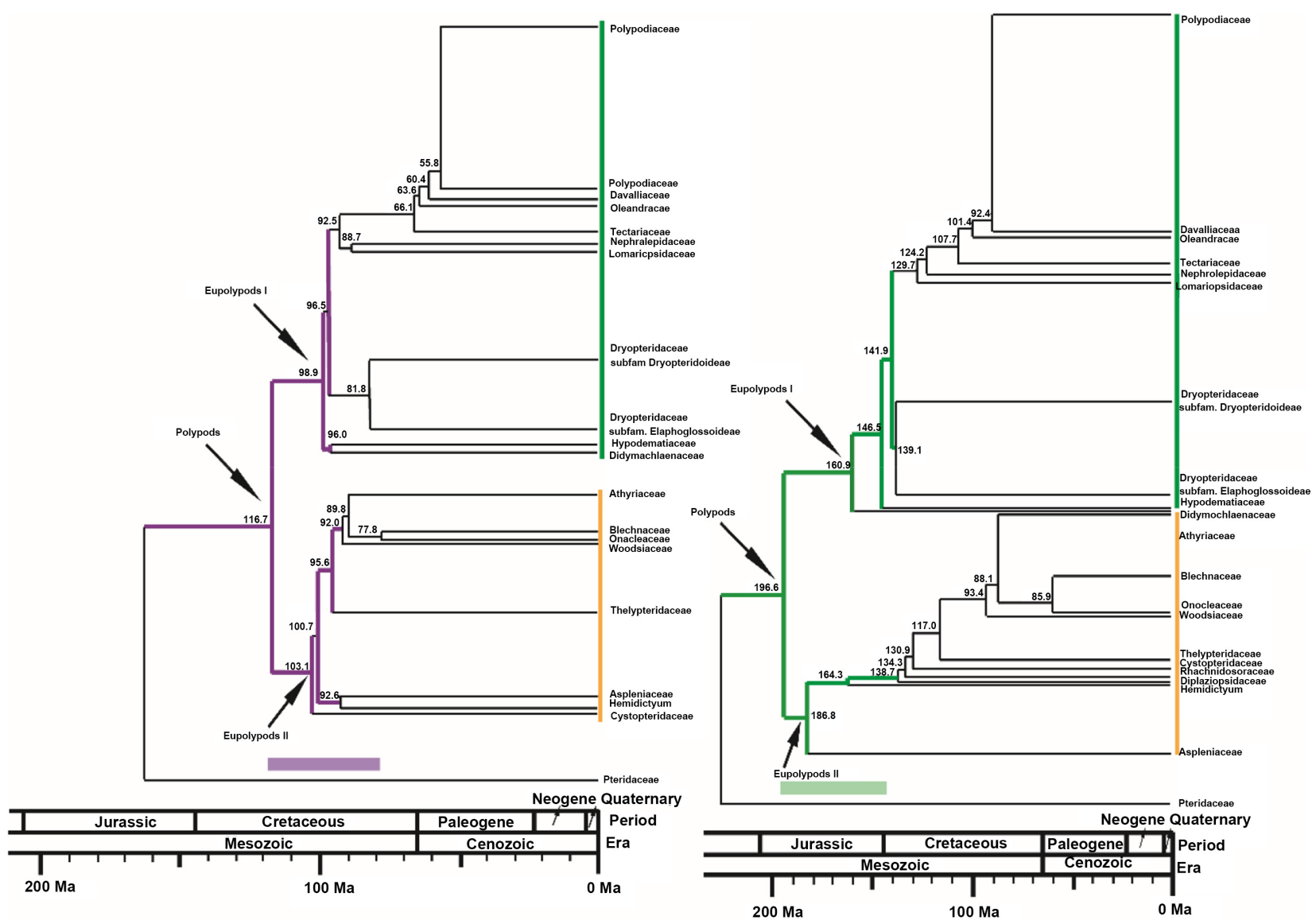

Figure 1. Eupolypod phylogenetic chronology based on the study of [4] (left) and [5] (right). Divergence time estimates for eupolypod lineages are indicated on the left side of the time tree.

However, the evolutionary history of the ferns remains incompletely understood, especially on its diversification scenarios, for example, most DNA-based divergence-time studies indicate that Eupolypods diversification occurred in the Late Cretaceous [2] [4], but Testo and Sundue [5] demonstrated that Eupolypods originated as early as in the Early Jurassic (Figure 1). The latter authors thought their age estimates to be much more realistic because they used more taxa (4000 taxa), a more advanced dating algorithm, and many more fossil calibrations with different placements. Although a range of molecular dating methods is now available, they all share a vital dependence on fossils as one of important age calibrations. It is therefore of prime importance to thoroughly document and critically evaluate new and informative fern fossils, especially those fossils from those periods of geologic time that are believed to represent important phases in the establishment and/or radiation of new fern lineages [6]. However, so far, no single study based on fossils from stratigraphic depositions has provided unequivocal evidence for a Cretaceous or pre-Cretaceous occurrence for Eupolypods [2] [7] [8] [9].

In the recent years, it has been found that approximately 100 million-year-old Myanmar ambers provide a unique source of polypod fossils. Eight fossils of 


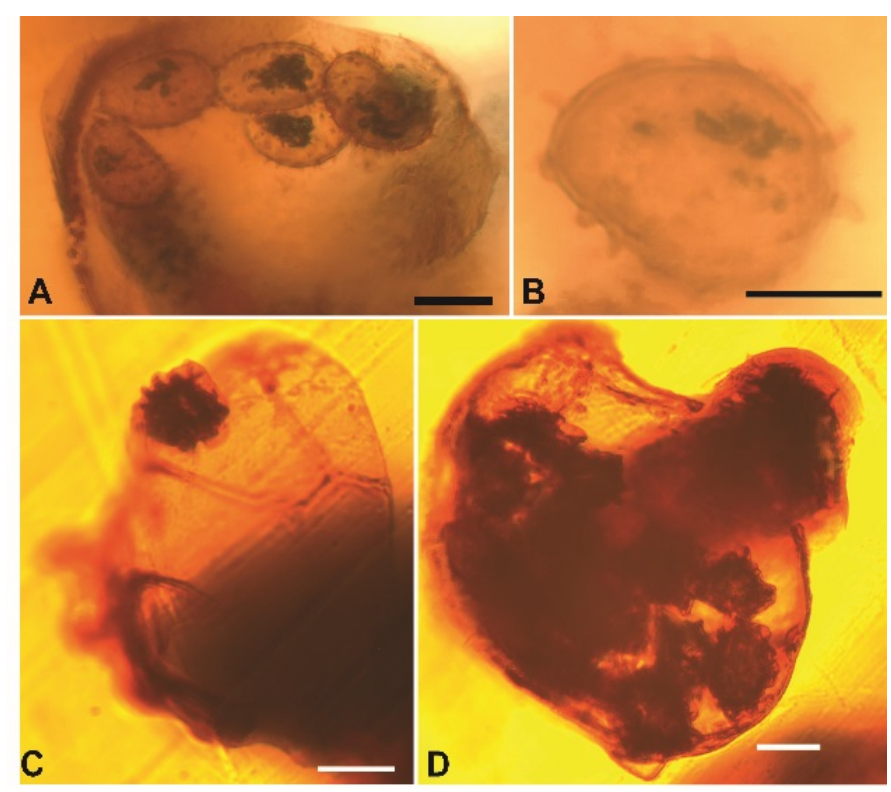

Figure 2. Eupolypod spores (monolete with distinct perine) in Cretaceous Myanmar amber ((A) (B), \#2016-03; CD, \#2018-67). Scale bars $=20 \mu \mathrm{m}(\mathrm{A})(\mathrm{C})(\mathrm{D})$, and $10 \mu \mathrm{m}(\mathrm{B})$.

different families and numerous sporangia, spores, and scales have been found in Myanmar ambers [6] [10]-[15], including eupolypod-like fossil Cretacifilix fungiformis [10], the first compelling eupolypod fossil Holttumopteris burmensis [6], eupolypod fossil scales, and spores (Figure 2). All these findings suggest that a diversity of eupolypod ferns was present already in the mid-Cretaceous Myanmar amber forests, clearly showing that Eupolypods originated before mid-Cretaceous, probably as early as the Early Jurassic, consistent with the divergence time estimates from the study of Testo and Sundue [5]. Myanmar amber is about to become the most important source of new information on mid-Cretaceous fern diversity, as work on the Myanmar amber deposits continues, new fossils will be discovered and described and can be used to refine reconstructions of fern evolution during this important period of geologic time (i.e., the Cretaceous Terrestrial Revolution, [16]), and eventually can be used to piece together the steps and stages in the evolution and radiation of the eupolypod ferns [6].

\section{Acknowledgements}

The research was supported by projects of State Key Laboratory of Palaeobiology and Stratigraphy (Nanjing Institute of geology and Palaeontology, Chinese Academy of Science) (Grant No. Y626040108) and Strategic Priority Research Program of Chinese Academy of Sciences (Grant No. XDB26000000). This is a contribution to UNESCO-IUGS IGCP Project 679.

\section{Conflicts of Interest}

The authors declare no conflicts of interest regarding the publication of this paper. 


\section{References}

[1] Smith, A.R., Pryer, K.M., Schuettpelz, E., Korall, P., Schneider, H. and Wolf, P.G. (2006) A Classification for Extant Ferns. Taxon, 55, 705-731. https://doi.org/10.2307/25065646

[2] Schneider, H., Schuettpelz, E., Pryer, K.M., Cranfill, R., Magallon, S. and Lupia, R. (2004) Ferns Diversified in the Shadow of Angiosperms. Nature, 428, 553-557. https://doi.org/10.1038/nature02361

[3] Lehtonen, S. (2011) Towards Resolving the Complete Fern Tree of Life. PLoS ONE, 6, e24851. https://doi.org/10.1371/journal.pone.0024851

[4] Schuettpelz, E. and Pryer, K.M. (2009) Evidence for a Cenozoic Radiation of Ferns in an Angiosperm-Dominated Canopy. Proceedings of the National Academy of Sciences USA, 106, 11200-11205. https://doi.org/10.1073/pnas.0811136106

[5] Testo, W. and Sundue, M. (2016) A 4000-Species Dataset Provides New Insight into the Evolution of Ferns. Molecular Phylogenetics and Evolution, 105, 200-211. https://doi.org/10.1016/j.ympev.2016.09.003

[6] Regalado, L., Schmidt, A.R., Krings, M., Bechteler, J., Schneider, H. and Heinrichs, J. (2018) Fossil Evidence for Eupolypod Ferns in the Mid-Cretaceous of Myanmar. Plant Systematics and Evolution, 304, 1-13. https://doi.org/10.1007/s00606-017-1439-2

[7] Collinson, M.E. (1996) What Use Are Fossil Ferns? 20 Years on: With a Review of the Fossil History of Extant Pteridophyte Families and Genera. In: Camus, J.M., Johns, R.J. and Gibby, M., Eds., Pteridology in Perspective, Royal Botanic Gardens, Kew, 349-394.

[8] Collinson, M.E. (2001) Cainozoic Ferns and Their Distribution. Brittonia, 53, 173-235. https://doi.org/10.1007/BF02812700

[9] Skog, J.E. (2001) Biogeography of Mesozoic Leptosporangiate Ferns Related to Extant Ferns. Brittonia, 53, 236-269. https://doi.org/10.1007/BF02812701

[10] Poinar, G.O. and Buckley, R. (2008) Cretacifilix fungiformis gen. and sp. nov, an Eupolypod Fern (Polypodiales) in Early Cretaceous Burmese Amber. Journal of the Botanical Research Institute of Texas, 2, 1175-1182.

[11] Regalado, L., Schmidt, A.R., Appelhans, M.S., Ilsemann, B., Schneider, H., Krings, M. and Heinrichs, J. (2017) A Fossil Species of the Enigmatic Early Polypod Fern Genus Cystodium (Cystodiaceae) in Cretaceous Amber from Myanmar. Scientific Reports, 7, Article No. 14615. https://doi.org/10.1038/s41598-017-14985-7

[12] Regalado, L., Schmidt, A.R., Müller, P., Kobbert, M.J., Schneider, H. and Heinrichs, J. (2017) The First Fossil of Lindsaeaceae (Polypodiales) from the Cretaceous Amber Forest of Myanmar. Cretaceous Research, 72, 8-12. https://doi.org/10.1016/j.cretres.2016.12.003

[13] Regalado, L., Schmidt, A.R., Müller, P., Niedermeier, L., Krings, M. and Schneider, H. (2019) Heinrichsia cheilanthoides gen. et sp. nov., a Fossil Fern in the Family Pteridaceae (Polypodiales) from the Cretaceous Amber Forests of Myanmar. Journal of Systematics and Evolution, 57, 329-338. https://doi.org/10.1111/jse.12514

[14] Li, C.X., Moran, R.C., Ma, J.Y., Wang, B. and Hao, J.S. (2018) A New Fossil Record of Lindsaeaceae (Polypodiales) from the Mid-Cretaceous Amber of Myanmar. Cretaceous Research. https://doi.org/10.1016/j.cretres.2018.12.010

[15] Li, C.X., Moran, R.C., Ma, J.Y., Wang, B., Hao, J.S. and Yang, Q. (2019) A Mid-Cretaceous Tree Fern of Thyrsopteridaceae (Cyatheales) Preserved in Myanmar Amber. Cretaceous Research. https://doi.org/10.1016/j.cretres.2019.01.002 
[16] Meredith, R.W., Janecka, J.E., Gatesy, J., Ryder, O.A., Fisher, C.A., Teeling, E.C., Goodbla, A., Eizirk, E., Simao, T.L., Stadler, T., Rabosky, D.L., Honeycutt, R.L., Flynn, J.J., Ingram, C.M., Steiner, C., Williams, T.L., Robinson, T.J., Burk-Herrick, A., Westerman, M., Ayoub, N.A., Springer, M.S. and Murphy, W.J. (2011) Impacts of the Cretaceous Terrestrial Revolution and K/Pg Extinction on Mammal Diversification. Science, 34, 521-524. https://doi.org/10.1126/science.1211028 